\title{
Plate tectonic aspects of the Triassic carbonate-hosted stratiform-stratabound base-metal deposits in the Western Balkan, NW Bulgaria
}

\section{Irina Marinova* and Zhelyazko Damyanov}

Bulgarian Academy of Sciences, Institute of Mineralogy and Crystallography, Acad. G. Bonchev Str., Block 107, 1113 Sofia, Bulgaria (*corresponding author: irimari@gmail.com)

65-73 4 Figs. 2 Pls.

doi: $10.4154 / \mathrm{gc} .2016 .05$

chess

Article history:

Received November 06, 2015

Revised and accepted December 09, 2015

Avaliable online February 29, 2016

Keywords: siderite-base metal deposits, Kremikovtsi-Vratsa ore district, Triassic metallogeny, Moesian carbonate platform

\begin{abstract}
The Triassic carbonate-hosted stratiform-stratabound base-metal deposits in the Western Balkan, NW Bulgaria, have well defined regional geological and tectonic settings, style of mineralisation, mineralogical, geochemical and isotopic data. Their genesis, however, remains controversial in the framework of plate tectonic models, and is not supported by comparative analysis of possible counterpart candidates within the NW Tethyan domain. Besides, the crucial missing information is the geochronology of ore mineralisation relative to the Triassic carbonate host rocks. The article stresses the ambiguities due to the lack of mineralisation age dating, and emphasises the necessity for building a convincing plate tectonic model based on the relevant geodynamic setting. A prospective direction of research is the critical comparison with equivalent sediment-hosted base-metal deposits within the continental margin environments such as those in the Alps and Dinarides as well as others in the Alpine-Himalayan orogen and worldwide.
\end{abstract}

\section{INTRODUCTION}

The Triassic carbonate-hosted stratiform-stratabound basemetal deposits in the Western Balkan, NW Bulgaria are medium- to small-sized deposits of lead, zinc, copper and silver located to the south of Vratsa town. They also include the large iron-manganese-barium (+subeconomic lead-zinc) Kremikovtsi deposit situated to the north of Sofia, together comprising the Kremikovtsi-Vratsa Ore District (POPOV, 1985) (Fig. 1).

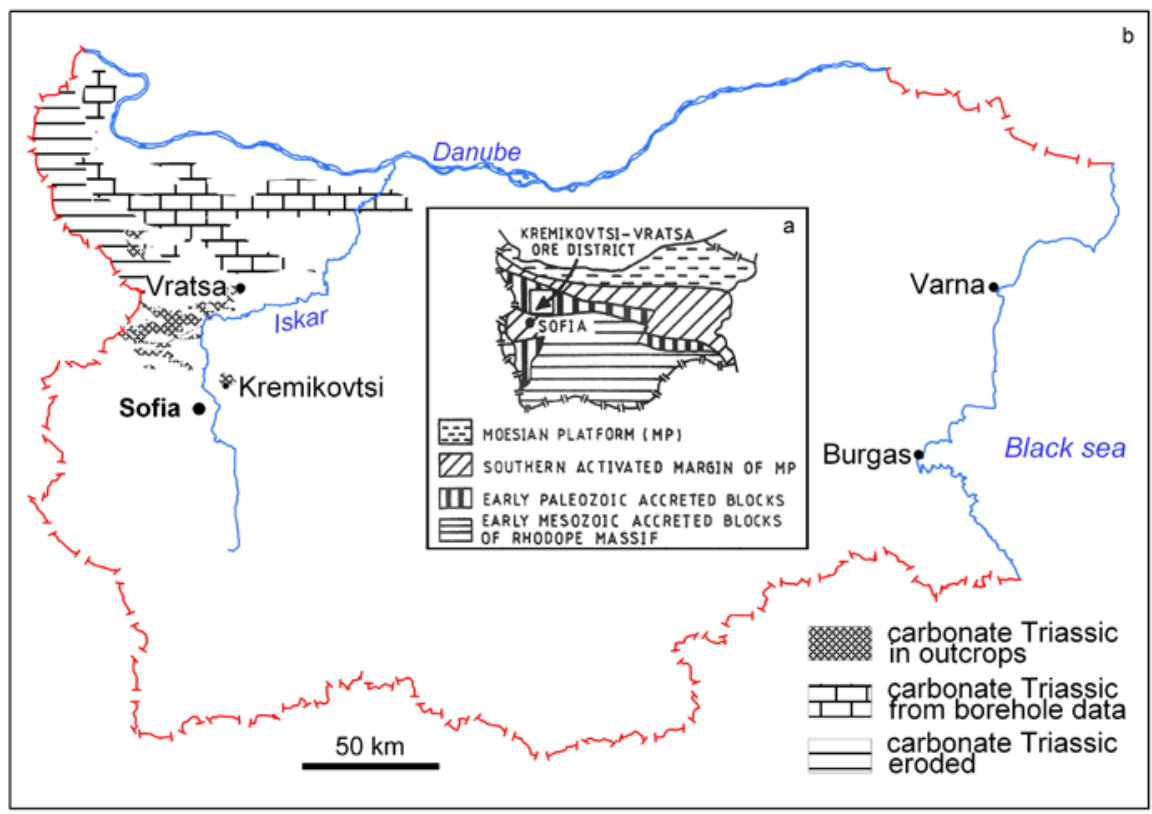

Figure 1. Location of the Kremikovtsi-Vratsa Ore District in the Bulgarian Early Mesozoic tectonic setting (a) from DAMYANOV (1995) and distribution of the carbonate Triassic formation in the NW Bulgaria (b) from ZAGORCHEV \& BUDUROV (2009).
These deposits share many similarities with the sedimenthosted base-metal deposits in the Alps and Dinarides (PALINKAŠ et al., 2014 and references herein), the CracowSilesian District in Poland (BANKS et al., 2003), Iran (RAJABI et al., 2013), and Ireland (HNATYSHIN et al., 2015), etc.

The Triassic sediment-hosted base-metal deposits in the Alps and Dinarides formed within the Adriatic-Dinaridic carbonate platform - a passive continental margin of Gondwana (PALINKAŠ et al., 2014). The Triassic carbonate-hosted base-metal deposits in the Western Balkan (Bulgaria) formed within the Balkan terrain - a PrecambrianCambrian ophiolite-island arc assemblage, unconformably overlain by a Palaeozoic sedimentary sequence. This terrain was accreted to the Palaeozoic basement of the Moesian platform (located to the northward) in Upper Carboniferous time. Basements of the Balkan and the Moesian terrains are of Gondwana origin (HAYDOUTOV \& YANEV, 1997). Thus, the Hercynian orogonesis resulted in closure of the Palaeo-Tethys and accretion of Gondwana and the Eurasian plate (DABOVSKI \& ZAGORCHEV, 2009).

The location of ancient and old mine workings are known for almost all deposits in the Western Balkan. It is believed that the Thracians were the first to start mining, followed by the Romans and then the Saxons. During the Ottoman rule, min- 
ers hired by the Republik of Dubrovnik, after primitive melting, carried the metal to Dubrovnik proper. In 1902, the modern mining industry in the Vratsa Ore District started with the opening of the Plakalnitsa mine. The mine had been operating for around 90 years until 1998, when the last mines were closed (PETROV et al., 2011). Unlike the Kremikovtsi deposit which has been known since the end of the $19^{\text {th }}$ century. Smallscale production began in 1913 . The modern production started in 1963 and continued until the early $21^{\text {st }}$ century.

The deposits in the Kremikovtsi-Vratsa Ore District were intensively explored and studied over a long time with the onset in the $1960-1990$ s of the $20^{\text {th }}$ century. Comprehensive researchers of the Vratsa ore region and the biggest Sedmochislenitsi deposit are ATANASOV (1972) and MINCHEVASTEFANOVA (1988) with their comprehensive reviews concerning the deposit mineralogy and geochemistry. Tectonics of the ore deposits were studied by KALAYDZIEV $(1977,1982)$, KALAYDZIEV \& POPOVA (1981) and by CHERNEV (1993). The Kremikovtsi deposit was studied by many researchers (review in KANOURKOV, 1988) among whom the studies of RATIEV (1977), KALAYDZIEV et al. (1982), KANOURKOV (1988), POPOV (1989), BAKARDZIEV \& POPOV (1995), and DAMYANOV (1993) are more comprehensive.

Past research constrained the general features of the deposits including the geological setting, tectonics, style of mineralisation, ore and gang mineralisation and geochemistry. Some issues, however, have remained unresolved. The dating of ores is based only on $\mathrm{Pb}$ isotope data, which remains controversial. The sources of metals and fluids are poorly defined, and the data on the geodynamic setting of the deposits needs updating. Hence, the genetic models created are very different and often contradictory.

The paper reviews the published data on the Triassic carbonate-hosted stratiform-stratabound base-metal deposits in the Western Balkan, NW Bulgaria concerning their geology and mineralogy. It illustrates the principal ore textures, briefing the main ideas on their origin, and outlines directions for future research. The primary goal is to clarify and confirm the relevant geodynamic setting in relation to the other Triassic sediment-hosted base-metal deposits within the continental margin environment, likewise equivalent deposits in Alps and Dinarides as well as the other similar deposits in the AlpineHimalayan orogen and worldwide.

\section{GEOLOGICAL FRAMEWORK}

The Western Balkan is part of the Balkan Orogenic Zone. To the East the Balkan Zone comprises the Central Balkan and Eastern Balkan units. The Western Balkan is composed of Neoproterozoic-Cambrian basement, poorly preserved $\mathrm{Pa}$ laeozoic mantle (mainly Permian variegated sediments) and Mesozoic cover of Triassic clastic and platform carbonate rocks, Lower to Middle Jurassic continental and shallow marine sediments overlain by Upper Jurassic - Lower Cretaceous sediments. In the Late Cretaceous the Western Balkan fall in compression mode as in the Middle Eocene it was thrust over the edge of the Moessian platform. During thrusting, the northern periphery of the Western Balkan was the primary zone of tectonic deformation (DABOVSKI \& ZAGORCHEV, 2009).

The deposits in the Kremikovtsi-Vratsa Ore District are mainly hosted by the Lower to Middle Triassic limestones, dolomitized limestones and dolostones in areas of their synclinal foldings. Base-metal mineralisations are also known in the Lower and Middle Jurassic carbonate-terrigenous rocks (e.g. the Breze iron deposit in the Western Balkan, KANOURKOV, 1988) and in the basement rocks (Vratsa Ore district, KANOURKOV, 1988; Kremikovtsi deposit, DAMYANOV, 1996, 1998) but of smaller extent.

The base-metal mineralisations in the Western Balkan crop out largely along the Iskar River where deeply incised valley display the thick Triassic sequence. The Iskar riverbed is at 300-400 $\mathrm{m}$ above sea level; the peaks in the Vratsa Balkan are high, at about 1300-1600 $\mathrm{m}$ a.s.l., and the relief is strongly incised. In the Western Balkan the Triassic carbonate rocks do not occupy a large area because denudation after the Triassic eroded most of the formation exposed in positive elevation structures (Fig. 1). The Triassic section in boreholes in the Moesian platform exceeds $1 \mathrm{~km}$ (VAPTSAROVA et al., 1979).

The area in the Western Balkan which hosts stratiformstratabound base-metal mineralisations is a part of the large Berkovitsa anticline which includes wide and flat second-order synclines and anticlines. It developed between the TriassicJurassic and the Upper Cretaceous (YOVCHEV, 1961). Its Palaeozoic core crops out along the Iskar River and comprises Hercynian intrusive rocks (granodiorites and granites). The latter are overlain discordantly by Upper Carboniferous quartzites, sandstones and coal-bearing argillites. Passing upwards, Permian terrigenous-volcanogenic rocks crop out. The Triassic sequence begins with a regional discordance - the Lower Triassic monogenic conglomerates and monomictic (quartz) to oligomictic sandstones overlie a variegated basement of PreCambrian rocks, Palaeozoic low-grade metamorphic and magmatic rocks or Permian red beds (Fig. 2). The exact age of the Triassic transgression is not known. The Triassic system in Bulgaria lacks discordances or discontinuities. A regional unconformity at the end of the Triassic and the beginning of the Jurassic is very well recorded as most tectonic units are related to the Early Cimmerian orogenic phase (BONCHEV, 1940). The Triassic formations developed after the Hercynian orogeny, following denudation of the expressive topography, deposition of the Lower Permian molasse type sediments and the Late Permian. Differential subsidence, accompanied by embryonic rifting (the Chiren rift in the West Balkan terrain) led to a marine transgression at the end of the Early Triassic and a marine regime in the Middle Triassic time with the foundation of the carbonate platform. At the end of the Triassic, activation of the Late Cimmerian orogenic phase began, followed by compression and weak folding which resulted in a gradual regression, leading to massive drainage over the entire Bulgarian territory. This regression was in contrast to development in the Dinarides, Albanides and Helenides where Mesozoic marine sedimentation was continued without interruption into the Neozoic (ZAGORCHEV \& DABOVSKI, 2009).

Triassic carbonate sedimentation was accompanied by magmatism, established to the north of the Vratsa Ore District and 


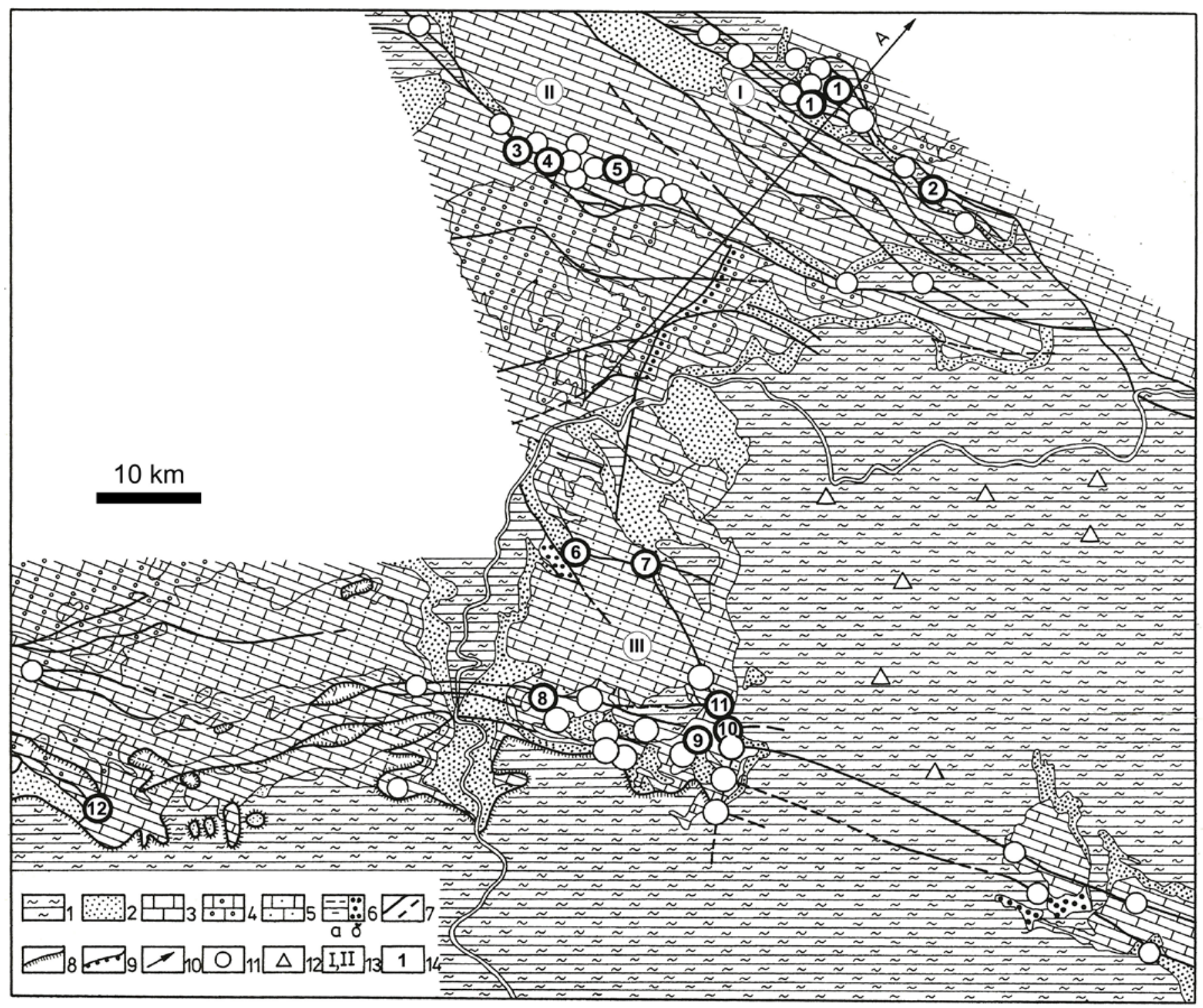

Figure 2. Geological map of the Vratsa Ore District (after Tronkov \& Mincheva-Stefanova, from MINCHEVA-STEFANOVA, 1988, with simplification): 1 - Palaeozoic rocks, 2, 3, 4 - Lower, Middle and Upper Triassic sediments, respectively, 5 - Jurassic sediments, 6a - Cretaceous sediments, $6 \mathrm{~b}$ - Quaternary sediments, 7 - fault, certain by continuous line, uncertain by dashed line, 8 - thrust or klippe, 9 - flexure, 10 - line of cross-section, 11 - base-metal deposit, in bold - major one, numbered, 12 - barite vein deposits, 13 - number of ore zone (I Vratsa, II - Pop-Sokolets, III - Izdremets), 14 - number of deposit: in the Vratsa ore zone - 1- Sedmochislenitsi; 2 - Plakalnitsa; in the PopSokolets ore zone - 3 - Majo, 4 - Balichin preslap, 5 - Gerana; in the Izdremets ore zone - 6 - Venetsa, 7 - Lakatnik, 8 - Hristo Botev, 9 Bakara, 10 - Zapachitsa, 11 - Rakov dol, 12 - Perovo.

within the Kremikovtsi region (CHEMBERSKI \& VAPCAROVA, 1979; DAMYANOV, 1993, 1996). In the Vratsa district, boreholes intersected lava flows of massive or amygdaloidal basalts, trachybasalts, and trachytes up to $40 \mathrm{~m}$ thick. The lava flows alternate with tuffs and epiclastites, while the volcaniclastic products in addition alternate with limestones and dolostones. This volcano-sedimentary alternation has a maximum thickness up to $160-200 \mathrm{~m}$. The volcanic activity began in the Olenekian $\left(\mathrm{T}_{1}\right)$ and continued to the Lower-Middle? Carnian $\left(\mathrm{T}_{3}{ }_{3}^{1}\right)$ with the most pronounced intensity in the Middle Triassic. The volcanism was high-potassium alkaline to transitional intraplate, related to rifting (CORTESOGNO et al., 2004). The Triassic magmatism in the Kremikovtsi district is represented by tuffs but it has been poorly studied.

The ore deposits and occurrences in the Vratsa Ore District are arranged along three regional, steep, normal faults of pre- dominant NW to E-W and WSW strike and length up to 700$800 \mathrm{~m}$, which are in order from the north to the south the: Plakalnitsa, Pop-Sokoletski and Izdremets faults (Fig. 2). YOVCHEV (1961) thought these faults were conduits for fluids from the Palaeozoic to the Oligocene and were responsible for the formation of the stratiform-stratabound base-metal deposits. MINCHEVA-STEFANOVA (1988), POPOV (1989) and CHERNEV (1993), considered that the locus of the basemetal mineralisation is placed at the intersections of these faults with other, less-pronounced ones, of northeastern strike. These tectonic relationships derived bias which attributed the stratiform-stratabound base-metal deposits in the Western Balkan to the post Lower Cretaceous by the latter authors.

The Kremikovtsi deposit is located within the Western Balkan Zone next to the Srednogorie Zone, located to the south. 

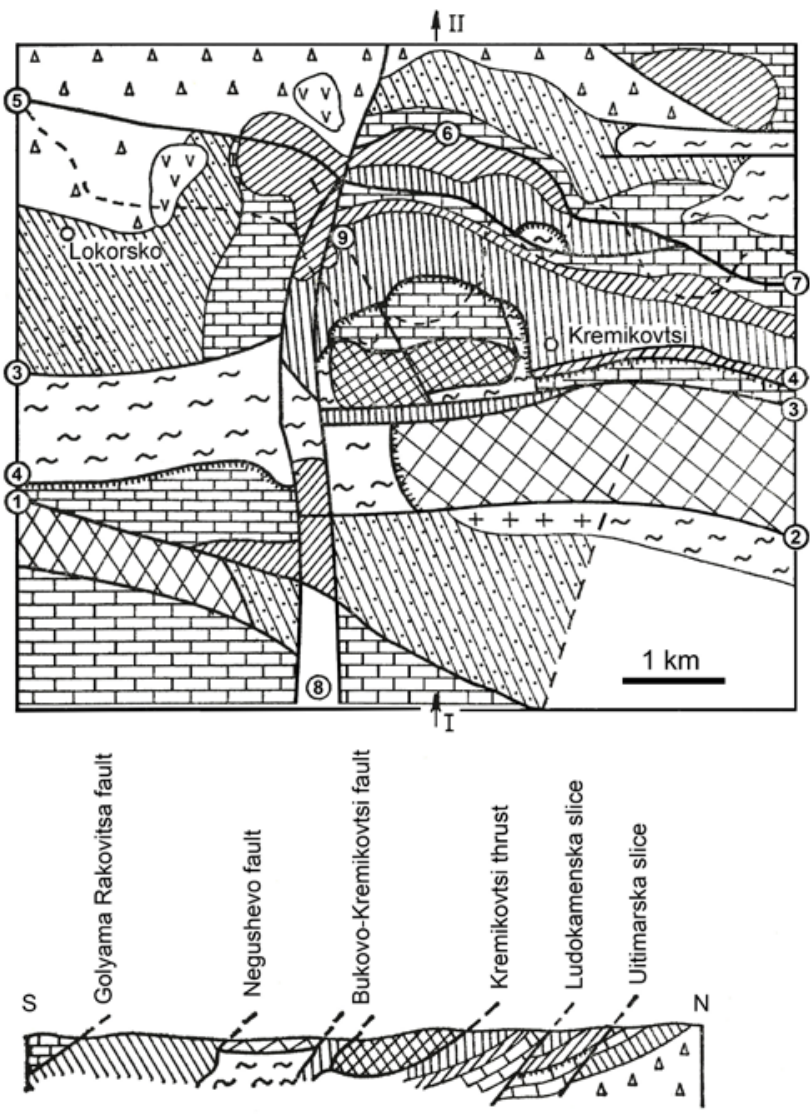

I - II

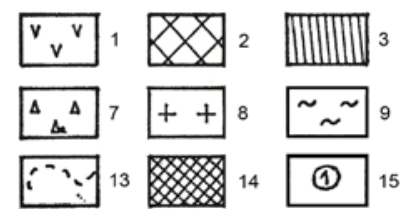

Figure 3. Geological map of the Kremikovtsi deposit and cross-section (without Pliocene and Quaternary sedimentary cover) (from KANOURKOV, 1988): 1 - Upper Cretaceous?: basaltic trachyandesites and trachyandesites; 2 - Senonian: marls and marly limestones; 3 - Tithonian-Berriasian flysch: sandstones, siltstones, marls and marly limestones; 4 - Hettangian-Kimmeridgian: sandstones, sandy and marly limestones, marls, and limestones; 5 - Early-Middle Triassic: limestones and dolomitized limestones; 6 - Early Triassic: sandstones; 7 - Permian: volcanogenic and terrigenous rocks; 8 - Early Carboniferous: alkaline syenites; 9 - Ordovician and Silurian: limestones and phyllites; 10 - rocks of uncertain age; 11 - fault; 12 - thrust; 13 - contour of the open pit in 1984; 14 - ore body; 15 - faults: 1 - Golyama Rakovitsa, 2 - Negushevo, 3 - BukovoKremikovtsi, 4 - Kremikovtsi thrust, 5 - Ludokamenski, 6 - Uitimarski, 7 - Potopski, 8 - Bratinski, 9 - Proboinishki.

The ore bodies are hosted by the allochthone of the Kremikovtsi thrust within the Triassic dolomitized limestones (Fig. 3).

The allochthone base facies are Palaeozoic phyllites, while Upper Cretaceous sediments succeed in the uppermost section. Sediments of Lower and Upper Triassic, Jurassic and Lower Cretaceous age are placed along the thrust plane. These facts determine the age of thrusting as Illyrian (KANOURKOV, 1988), and imply that the main stratiform ore bodies were already formed during the Triassic, contemporaneously with the Triassic host carbonate rocks (DAMYANOV, 1996). Then, the deposit was translated to the NW over a $1.5 \mathrm{~km}$ distance during the thrust.

\section{MINERAL COMPOSITION OF THE BASE-METAL MINERALISATIONS}

In the Vratsa Ore District, MINCHEVA-STEFANOVA (1988) distinguished two base-metal ore types: (1) The lead-zinc and (2) The lead-copper $(\mathrm{Pb}-\mathrm{Cu}-\mathrm{Ag} \pm \mathrm{Bi})$. Based on their relationships, the author considered the two types as having been formed in the same temporal order. (1) The lead-zinc type comprises the following mineral parageneses: (i) pre-ore dolomitization; (ii) pyrite; (iii) dolomite-sphalerite; (iv) galena-sphalerite; (v) galena; (vi) calcite; (vii) dolomite, and (viii) barite-dolomite. (2) The lead-copper ( $\mathrm{Pb}-\mathrm{Cu}-\mathrm{Ag} \pm \mathrm{Bi}$ ) type bears (i) barite; (ii) tenantitebornite-chalcopyrite; (iii) galena; (iv, v) two silver parageneses, and (vi) late calcite paragenesis. The (iv,v) silver-rich parageneses contain various silver sulfosalts which predominate as well as silver sulfide, rare native silver, cinnabar and balkanite $\left(\mathrm{Cu}_{9} \mathrm{Ag}_{5} \mathrm{HgS}_{8}\right)$. Mineral balkanite was found for the first time in the Sedmochislenitsi deposit and was named after the Balkan Mt., the place of recognition, by ATANASOV (1972).

The formation of pre-ore dolomitization occurred at 140$120^{\circ} \mathrm{C}$, tenantite-bornite-chalcopyrite mineralisation around $200^{\circ} \mathrm{C}$, and the rest of parageneses formed at lower temperature $\left(100-70^{\circ} \mathrm{C}\right)$ (MINCHEVA-STEFANOVA, 1988). The great number of parageneses suggests a prolonged time of mineralisation formation. CHERNEV (1993) came to the same conclusion implying tectonic data.

The Kremikovtsi deposit contains the following primary ore types with the respective economic commodities: siderite, haematite, barite and galena. The gangue minerals in the siderite ore are microquartz, berthierine, chamosite, ferroan dolomite and ankerite. The principal gangue minerals in the haematite ore are microquartz and calcite (DAMYANOV, 1996, 1998). The barite ore contains quartz, calcite, ferroan dolomite and ankerite, while the lead ore comprises dolomite in addition. The siderite and haematite ore bodies are mainly massive and finely banded. The barite bodies have both a massive and vein appearance. The galena ore displays disseminated and replacement textures.

\section{STYLES OF BASE-METAL MINERALIZATION AND ORE TEXTURES}

\subsection{VRATSA ORE DISTRICT}

The base-metal mineralisation in the Vratsa Ore District is mainly stratiform and lens-shaped with a length commonly of 400$500 \mathrm{~m}$ and thickness about $10 \mathrm{~m}$ (Fig. 4).

Impregnations of the host rocks are very common and stockwork bodies also occur (YOVCHEV, 1961; KALAYDZIEV et al., 1982; MINCHEVA-STEFANOVA, 1988). The dip of stratiform ore bodies is consistent with the host sediments (Fig. 4). Vein morphology is very rare. KALAYDZIEV (1982) estimated that in the Sedmochislenitsi deposit around $80 \%$ of the ore bodies are hosted by dolostones and around $20 \%$ in dolomitized limestones. He related this fact to the increased fracturing of the dolomitic rocks.

The Triassic limestones are micritic (Pl. 1a) and the dolostones are formed by the diagenetic dolomitization of limestones, and both appear dark grey to black. The diagenetic dolomitization of limestones was even determined in the earliest studies (references in MINCHEVA-STEFANOVA, 1988). The 


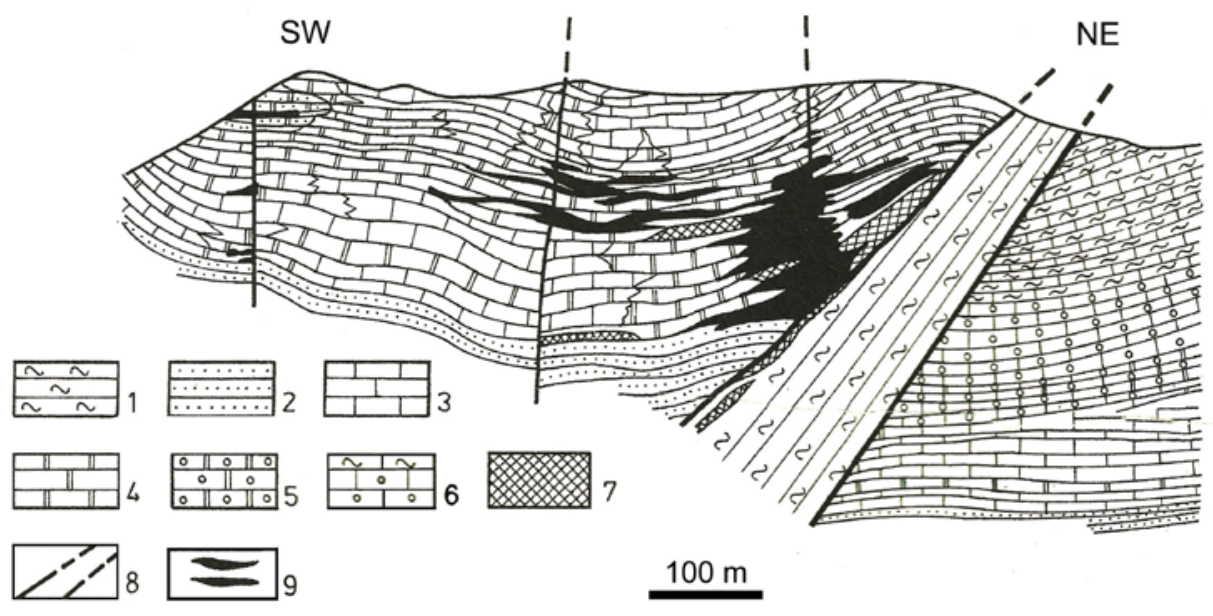

Figure 4. Cross-section the Sedmochislenitsi syncline and deposit (from MINCHEVA-STEFANOVA, 1988): 1 Carboniferous sediments, 2 - Lower Triassic sediments, 3 - Anisian limestones, 4 - Anisian dolostones, 5 - Ladinian sediments, 6 - Upper Triassic sediments, 7 - mylonite, 8 - faults, 9 - ore bodies.
Triassic carbonate rocks are dense, of massive texture. Sulfides occur as replacements, open-space fillings (crack and vug fillings), colloform masses, and disseminations (Pl. 1).

In the Vratsa Ore District, CHERNEV (1993) defined three types of ore bodies in Mesozoic carbonate rocks disregarding the ore composition: (i) ore bodies in the lithology favourable for ore precipitation, (ii) ore bodies in the intersections of folds of different strikes, and (iii) ore bodies with upper or lower boundaries unconformable to the bedding. The first type is predominant in the Vratsa District. The author underlined that this type does not display a relationship to faults and looks like a syngenetic one. The formation of the second type is favoured by the high degree of fracturing due to interference of cleavages in the intersections of folds of different strikes, and to the development of extensional fracturing along the bedding. In other cases, the fold cleavage does not display a relationship with the sulfide mineralisation. The third type is a result of the combination of favourable lithology and brecciation/or fracturing.

POPOV et al. (1989) counted the density of fractures in the host dolostones in the Plakalnitsa deposit and yielded 200-300 per $\mathrm{m}^{3}$, while in the host limestones their number was 20-30 per $\mathrm{m}^{3}$, evidencing the importance of fracturing for ore deposition. Several authors (ATANASOV, 1973; KALAYDZIEV \& POPOVA, 1981; MINCHEVA-STEFANOVA, 1988; CHERNEV, 1993) paid attention to the relationship of some deposits to local deflexion of the regional Plakalnitsa and Pop-Sokolets faults. Such deflexions form extensional jogs and contain ores. ATANASOV (1973) pointed out that the thickness of ore bodies increases when approaching some steep faults forming stocklike thickening of highly brecciated and mineralised host rocks. KALAYDZIEV (1982) demonstrated by geological cross-sections that steep normal faults either transposed stratiform bodies or have no effect on their spatial position. The afore-mentioned authors agree that openings along the bedding were favourable for ore deposition. Marl intercalations and thin-bedded dolostone packets were considered to be a screen for the ore fluids (KALAYDZIEV, 1982), while organic matter was a chemical reducer (MINCHEVA-STEFANOVA, 1988).

Another structural factor is the intense fracturing of sediments near the regional faults. These areas contain sulfide mineralisation (CHERNEV, 1993).
The micritic texture predetermines the main fine-grained massive texture of the ores. The replacement origin of the massive texture is evidenced by relics of the host carbonate grains inside the sulfide $(\mathrm{Pl} .1 \mathrm{a}-\mathrm{c})$. A second distribution type has the colloform texture of sphalerite and pyrite (Pl. 1e-f). The individual crystals are very fine - commonly several microns. Usually, the individual minerals are ultimately mutually intergrown. The presence of both sparry dolomite and sulfides in dolomitized micritic limestone indicates the simultaneous deposition of sparry dolomite and sulfides (Pl. 1d). In places, colloform pyrite consists of minute globular grains suggesting aggregation of colloidal particles ( $\mathrm{Pl}$. $1 \mathrm{~g})$. Later carbonates have corroded the base-metal mineralisation (Pl. 1h).

\subsection{KREMIKOVTSI DEPOSIT}

In the Kremikovtsi deposit the siderite, haematite and barite bodies in the Triassic carbonate rocks are presented in lenses and beds, while the lead-rich bodies have pipe-like and lens morphologies. Thus, the ore bodies are stratiform and bound to the Triassic carbonates. The mineralisation in the Palaeozoic basement is cross-cutting, hosted by faults of the feeder zone (DAMYANOV, 1996, 1998).

The siderite ore is mainly composed of fine-grained $\mathrm{Mg}$ Mn siderite with massive texture rarely intercalated by fine clayey bands enriched in organic matter (Pl. 2a). Siderite is associated with microquartz cementing the carbonate aggregates (Pl. 2b) and fine- to medium-grained barite with sulfides and authigenic phyllosilicates forming veinlets, nests and impregnations (Pl. $2 \mathrm{c}-\mathrm{f}$ ).

The barite mineralisation is widespread in the iron formations of the Kremikovtsi deposit (Pl. $2 \mathrm{c}-\mathrm{g}$ ) and is one of the world's largest hosts of barite concentrations and reserves. Coarse-grained tabular barite crystals form the main lenticular or subvertical veined barite ore bodies.

Haematite ore is composed of fine-grained or tabular to flaky haematite (specularite) with a massive texture associated occasionally with barite veinlets and nests and $\mathrm{Ca}-\mathrm{Mg}$ siderite cement (Pl. $2 \mathrm{~g}, \mathrm{~h}$ ). Although significant quantities of $\mathrm{Pb}$ and $\mathrm{Ag}(+\mathrm{Cu}, \mathrm{Zn}, \mathrm{Hg}, \mathrm{Sb})$ have accumulated in the Kremikovtsi deposit the sulfide mineralisation is disseminated, low-grade and still uneconomic. 

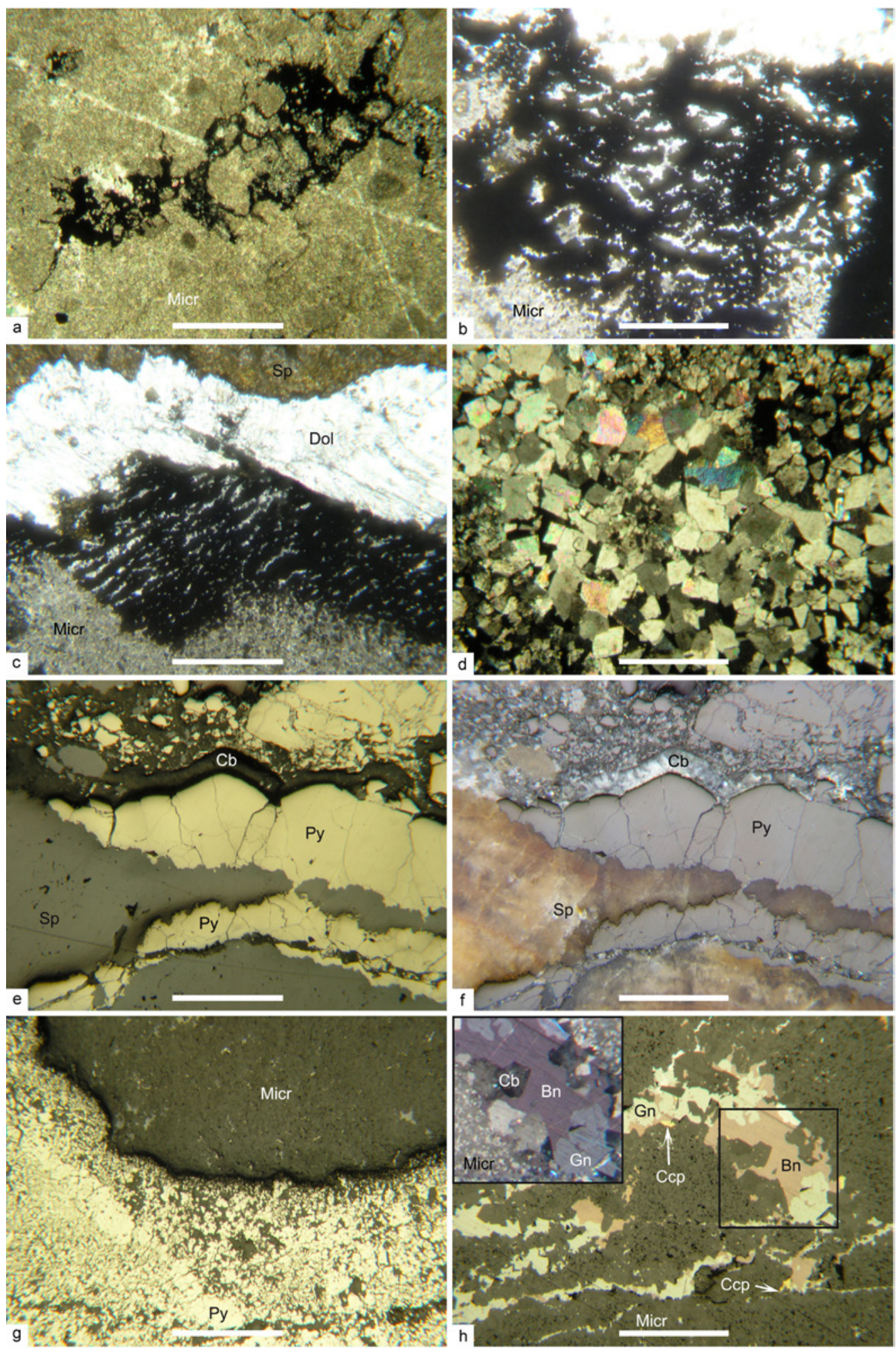

Plate 1

Photomicrographs of base-metal mineralisation from the Sedmochislenitsi deposit, the biggest deposit in the Vratsa Ore District (a-d - in transmitted light, $\mathrm{e}-\mathrm{h}$ - in reflected light):

a-micritic dolomitized limestone with sulfides along micro-cracks and as vug filling, xpl;

b - replacement of micritic dolomitized limestone by sulfide with inclusions of re-crystallized carbonate within the sulfide, ppl;

c - rhythmic replacement of dolomite by sulfide in micritic limestone, $\mathrm{xpl}$;

d-sparry dolomite in micritic limestone. The interstices of dolomite crystals are filled with sulfides (black), xpl;

e-f - colloform sphalerite, pyrite and carbonate in micritic dolomitized limestone (e in xpl, $\mathrm{f}-$ in ppl);

$\mathbf{g}$ - colloform pyrite aggregate built up of minute globular grains in micritic limestone, $\mathrm{xpl}$;

$\mathbf{h}$ - bornite-chalcopyrite-galena assemblage corroded by late sparry carbonate, xpl; inset in ppl.

Scale bar: in a, b, c, g, h-1 mm; in d, e, f - $0.5 \mathrm{~mm}$. Abbr.: ppl - plane polarized light, $\mathrm{xpl}$ - cross polarized light, Micr - micritic, $\mathrm{Sp}$ - sphalerite, Dol - dolomite, $\mathrm{Cb}$ - carbonate mineral, $\mathrm{Py}$ - pyrite, $\mathrm{Bn}$ - bornite, $\mathrm{Gn}$ - galena, Ccp - chalcopyrite. 

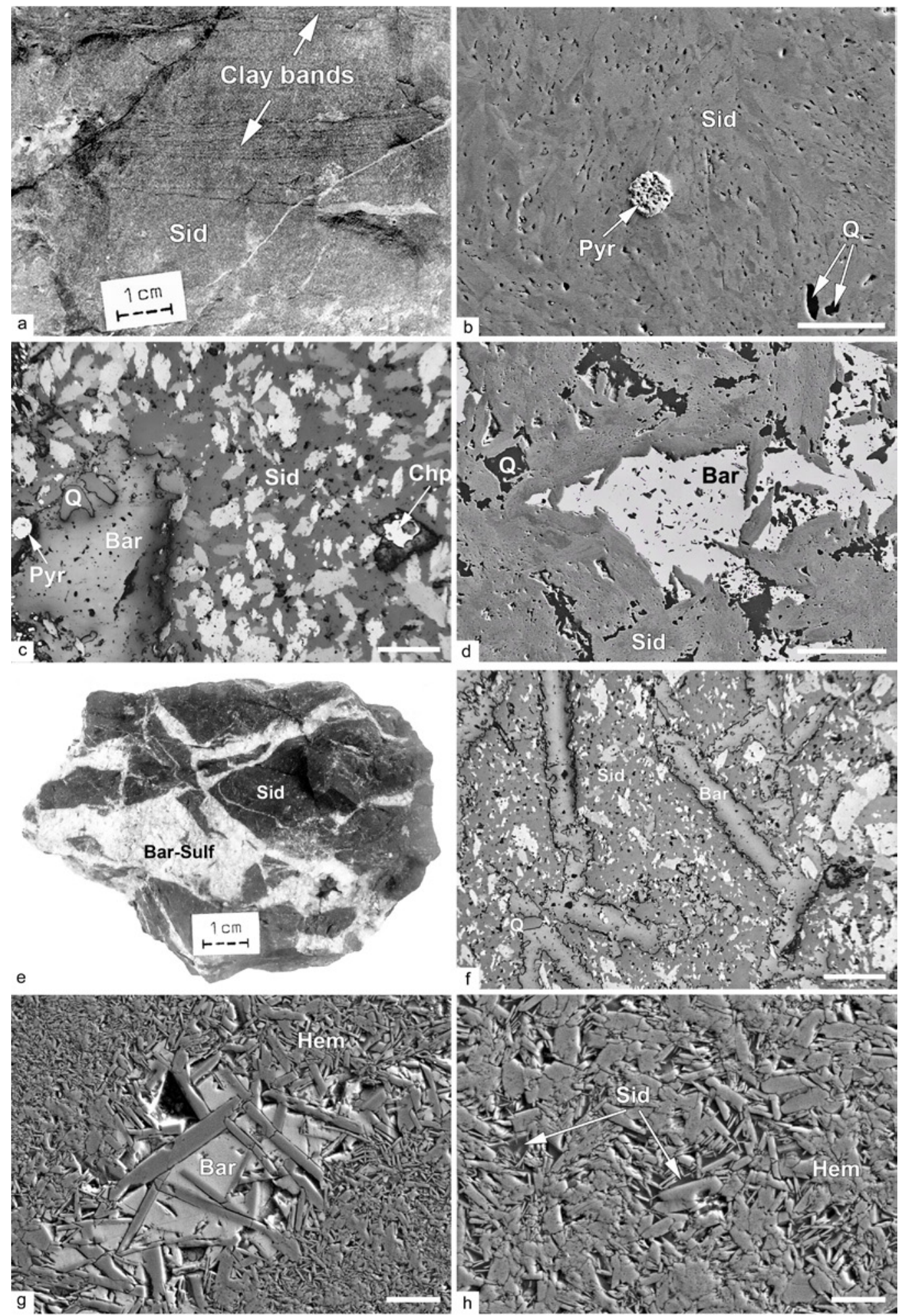

Plate 2

Photomicrographs of primary ore types in the Kremikovtsi carbonate-hosted iron-barite-sulfide deposit (b, d, g, h-SEM; c, f - reflected light): a - massive siderite intercalated with fine clayey bands enriched in organic matter, outcrop;

$\mathbf{b}$ - massive siderite with microquartz cement in interstices and framboidal pyrite;

c - massive medium-grained siderite associated with barite, quartz, framboidal pyrite and chalcopyrite;

d - barite nest in massive siderite with microquartz cementing carbonate grains;

e - veinlets and nests of coarse-grained barite associated with base-metal sulfides in hydrothermally re-crystallized sparry siderite;

f - massive medium-grained siderite associated with tabular barite impregnations and quartz;

$\mathbf{g}$ - barite veinlet in massive flaky hematite (specularite);

$\mathbf{h}$ - massive fine-grained and tabular hematite with siderite cement.

Scale bar: b- $30 \mu \mathrm{m}$; d - $50 \mu \mathrm{m}$; c, f-250 $\mu \mathrm{m}$; g-h - $10 \mu \mathrm{m}$. Abbr.: Sid - siderite, Bar - barite, Q - quartz, Pyr - pyrite, Chp - chalcopyrite, Sulf - sulfides. 


\section{AGE OF MINERALISATION AND SULFUR ISOTOPES}

Attempts to date the base-metal mineralisations in the Vratsa Ore District were made using the $\mathrm{U} / \mathrm{Pb}$ geochronology of galena. The results fell into two groups: the first with a model age of 240-270 Ma (Permian-Triassic), older than the host Triassic carbonates; the second with the Late Lower Cretaceous model age of $120 \mathrm{Ma}$ (review in MINCHEVA-STEFANOVA, 1988).

Lead isotopes of the main ore stage in the Kremikovtsi deposit gave a Palaeozoic model age ( 310 Ma, Middle/Upper Carboniferous; AMOV et al., 1977) with grouping into two subsets: "younger $\mathrm{Pb}$ " in lower beds and "older $\mathrm{Pb}$ " in upper beds. This fact was explained by DAMYANOV (1995) applying intense mixing of ore fluids in a two-stage hydrothermal system: the earlier one, related to hydrothermal sedimentation on the sea floor followed by diagenesis, and a later one of epigenetic origin, when boiled fluid in feeder zones deposited stockwork and vein barite/base-metal mineralisations in the host Triassic carbonate rocks and the Palaeozoic basement as well.

The isotopic composition of sulfide (pyrite, galena, and sphalerite) from the Vratsa Ore District (DIMITROV et al., 1986) is similar to that from the Mississippi Valley stratiform deposits (OHMOTO \& RYE, 1979). The range of $\delta^{34} \mathrm{~S}$, \%o for pyrite is from -27 to +15 , for galena from -24 to +14 , and for sphalerite from -15 to -4.5 , as the average $\delta^{34} \mathrm{~S}$, \%o for each sulfide has a negative value. The high scattering of $\delta^{34} \mathrm{~S}$ values was explained with different sulfur sources, leaching of sulfur from host rocks and biogenic reduction of the sulfate anion (DIMITROV et al., 1986). These authors established the lowermost radiogenic lead as galena in the Vratsa Ore District compared to other lead-zinc and copper deposits in Bulgaria.

\section{GENETIC MODELS}

Styles of mineralisation, stratiform and stratabound, and those cross-cutting the Triassic strata, as well as three consequent tectonic phases, and the controversial $\mathrm{U} / \mathrm{Pb}$ ages of galena, have led to a great variety of genetic models: telethermal, synsedimentary, epigenetic hydrothermal, hydrothermal-metasomatic, sedimentary-hydrothermal, sedimentaryexhalative (review in MINCHEVA-STEFANOVA, 1988; DAMYANOV, 1995). In addition, the Late Cretaceous magmatism, (the only evidence of igneous activity in the area till recently), linked the formation of the deposits with the magmatism as both the driving force and source of fluids. More recently, the finding of Triassic magmatic rocks in boreholes to the north of the Kremikovtsi-Vratsa Ore District has changed the views of researchers. Taking into account the presence of Triassic basaltic magmatism in the area, DAMYANOV (1995) presented the concept about the Triassic rift origin of the stratiform-stratabound deposits in the West Balkan. The Triassic rift in Bulgaria is an embryonic one because of the very constrained spatial distribution of the basaltic magmatism. On the other hand, PALINKAŠ et al. (2014) consider the Triassic SEDEX and Mississippi Valley type (MVT) deposits in the Alps and Dinarides as a result of advanced rifting. As a corollary, the Triassic deposits in the Alps and
Dinarides, and those in the Western Balkan, display a common geodynamic setting - Triassic rifting. These fruitful ideas need further confirmation through the united efforts of geologists from different countries.

\section{CONCLUDING REMARKS}

In conclusion, it should be stressed that the timing of the Triassic carbonate-hosted base-metal mineralisations in the Western Balkan is unknown. We have to expect ages ranging from the Triassic to post-Early Cretaceous bearing in mind the presence of different mineralisation styles and the protracted tectonic reworking of the Triassic host rocks, including the Early and Late Cimmerian tectonic phases and the Austrian phase. The recent advantages of isotopic methods for dating of sulfides like the $\mathrm{Os} / \mathrm{Re}, \mathrm{Rb} / \mathrm{Sr}$, and $\mathrm{Sm} / \mathrm{Nd}$ geochronology would be very useful for solving the existing problems. The experience with $\mathrm{Os} / \mathrm{Re}$ dating of pyrite from the Irish $\mathrm{Pb}-\mathrm{Zn}$ sediment-hosted deposits (HNATYSHIN et al., 2015), Rb/Sr dating of sphalerite from Australian MVT deposits (CHRISTENSEN et al., 1995), and Sm/ Nd dating of $\mathrm{Pb}-\mathrm{Zn}$ ore (JIANG et al., 2000) are successful examples suggesting one direction for future research. Another isotopic ratio, e.g. of $\mathrm{O}, \mathrm{H}$ and $\mathrm{C}$ would elucidate the poorly constrained sources of metals and fluids.

\section{Acknowledgment}

The National Museum "Earth and Man", Sofia is greatly acknowledged for the hand specimens from the Sedmocislenitsi deposit. The authors express their gratitude to the reviewers L. PALINKA $\breve{S}$ and S. PALINKAS̆ for the manuscript improvements and language handling.

\section{REFERENCES}

AMOV, B., BOGDANOV, B. \& BALDZIEVA, C. (1977): Lead isotope composition and some questions about the origin and age of mineralizations in Southern Bulgari.- In: Problems of ore deposits formation, Vth Symposium, Varna, 2, 13-25.

ATANASOV, V. (1972): Mineralogy of the copper-lead-zinc stratiform Sedmochislenitsi deposit, Bulgaria.- PhD thesis, Institute of Geology and Geophysics, Siberian branch of the Russian Academy of Sciences, Novosibirsk, 398 p. (in Russian).

ATANASOV, V. (1973): On the structure and natural boundaries of the Sedmochislenitsi copper-lead-zinc deposit, Western Stara Planina Mt.- Annual Higher Inst. Min. Geol., Sofia, 19/2, 1-17 (in Bulgarian, with English summary).

ATANASOV, V. \& KIROV, G. (1973): Balkanite, Cu9Ag5HgS8, a new mineral from the Sedmochislenitsi mine, Bulgaria.-Am. Mineralogist, 58, 11-15.

BAKARDZIEV, S. \& POPOV, P. (1995): Geological-structural features of the deposit.- In: The Kremikovtsi barite-iron deposit and the Jurassic system in the region, Guidebook, Mining and Geol. Univ., Sofia, 2-4, 10-15 (in Bulgarian).

BANKS, D., SCHNIDER, J., KUCHA, H. \& KEPPENS, E. (2003): CarbonateHosted Zn-Pb Deposits in Upper Silesia, Poland: Origin and Evolution of Mineralizing Fluids and Constraints on Genetic Models.- Econ. Geol., 98/5, 911-932.

BONCHEV, E. (1940): Alpine tectonic manifestations in Bulgaria.- Rev. Bulgarian Geol. Soc., 12/3, 155-227 (in Bulgarian).

CHEMBERSKI, H. \& VAPCAROVA, A. (1979): The Triassic system in North Bulgaria. I. Stratigraphic principles.- Geologica Balcanica, 9/1, 67-108 (in Russian, abstract in English).

CHERNEV, E. (1993): Formation conditions of the Alpine base-metal ore fields in the Vratsa Ore Unit.- Ph.D. Thesis, Sofia (in Bulgarian).

CHRISTENSEN, J., HALLIDAY, A., VEARNCOMBE, J. \& KESLER, S. (1995): Testing models of large-scale fluid flow using direct dating of sulfides; $\mathrm{Rb}-\mathrm{Sr}$ evidence for early dewatering and formation of Mississippi 
valley-type deposits, Canning basin, Australia. $\urcorner$ Econ. Geol., 90/4, 877-884. doi: 10.2113/gsecongeo.90.4.877

CORTESOGNO, L., GAGGERO, L. \& YANEV, S. (2007): Anorogenic volcanism in the Triassic sequences at the boundary of the Moesian plate.- Geodin. Acta, 17/1, 55-69. doi: 10.3166/ga.17.55-69

DABOVSKI, C. \& ZAGORCHEV, I. (2009): Alpine tectonic division of Bulgaria.- In: ZAGORCHEV, I., DABOVSKI, C. \& NIKOLOV, T. (eds): Geology of Bulgaria, Vol. II., Part 5. Mesozoic Geology, Sofia, Prof. Marin Drinov Publ. House, 30-37 (in Bulgarian).

DAMYANOV, Z. (1993): Mineralogical features and genesis of the sideritebearing ores from the Kremikovtsi deposit.- Unpubl. Ph.D. Thesis, Sofia.

DAMYANOV, Z. (1995): Triassic metallogenesis in the West Balkan.- Compt. Rend. Acad. Bulg. Sci., 48/11-12, 75-78.

DAMYANOV, Z. (1996): Genesis of the Kremikovtsi deposit and metallogenic perspectives of the Sredec iron ore region.- Geologica Balc., 26/4, 3-24.

DAMYANOV, Z. (1998): Ore petrology, whole-rock chemistry and zoning of the Kremikovtsi carbonate-hosted sedimentary exhalative iron $(+\mathrm{Mn})$-barite-sulfide deposit, Western Balkan, Bulgaria.- N. Jb. Miner. Abh., 174/1, $1-42$.

DIMITROV, R., BOGDANOV, K., BRESKOVSKA, V., MANKOV, S., AREVADZE, D. \& JAROSHEVICH, V. (1986): Isotopic Composition of Sulfur from Lead-Zinc and Copper Ore Deposits in Bulgaria.- Ore-form. Processes and Mineral Dep., 25, 3-21 (in Bulgarian, with English summary).

HAYDOUTOV, I. \& YANEV, S. (1997): The Protomoesian microcontinent of the Balkan Peninsula - a peri-Gondwanaland piece.- Tectonophysics, 272, 303-313.

HNATYSHIN, D., WILKINSON, J. \& GLEESON, S. (2015): Re-Os dating of pyrite confirms on early diagenetic onset and extended duration of mineralization in the Irish $\mathrm{Zn}-\mathrm{Pb}$ ore field.- Geology, 43/2, 143-146.

JIANG, S., SLACK, J. \& PALMER, M. (2000): Sm-Nd dating of the giant Sullivan Pb-Zn-Ag deposit, British Colombia.- Geology, 28/8, 751-754.

KALAYDZIEV, S. (1977): New data on the structural and lithological factors influenced the location of base-metal mineralisations in the Izdremets deposit, Western Stara Planina.- Ore-form. Processes and Mineral Dep., 6, 3-16 (in Bulgarian, with English summary).

KALAYDZIEV, S. (1982): New data on the structural peculiarities of the Kremikovtsi Ore Field.- Rev. Bulgarian Geol. Soc., 43/2, 159-171 (in Bulgarian).

KALAYDZIEV, S. \& POPOVA, P. (1981): Structural features of the stratiform Plakalnitsa deposit, Western Stara Planina.- Rev. Bulgarian Geol. Soc., 42,/1, 17-29 (in Bulgarian, with English summary).

KALAYDZIEV, S., LILOV, C., VALCHEV, V. \& TOSHKOV, A. (1982): New Data on the Morphological Peculiarities of Ore Bodies in the Sedmochislenitsi Polymetallic Deposit.- Ore-form. Processes and Mineral Dep., 17, 34-49 (in Bulgarian, with English summary).
KANOURKOV, G. (1988): The iron deposits in Bulgaria.- Technika, Sofia, 282 (in Bulgarian, with English summary).

MINCHEVA-STEFANOVA, Y. (1988): Sediment-hosted polymetallic deposits in the Western Stara Planina Mt.- In: DIMITROV, R. (ed.): The lead-zinc deposits in Bulgaria, Technika, Sofia, 175-192 (in Bulgarian).

OHMOTO, H. \& RYE, O. (1979): Isotopes of Sulfur and Carbon.- In: BARNES, H. (ed.): Geochemistry of hydrothermal ore deposits, Wiley, New York, 509-567.

PALINKAŠ, L., DAMYANOV, Z., BOROJEVIĆ, S., STRIMIC, S. \& MARINOVA, I. (2014): Divergent rifting separation of Adriatic-Dinaric and Moesian carbonate platforms witnessed by Triassic MVT and SEDEX deposits, Metallogenic approach.- Proc. XX CBGA Congress, Tirana, 24-26 Sept. 2014, 2, 428-431

PETROV, P., ATANASOVA, S., NESHEVA, L. \& KUNOV, A. (2011): Preserved mineral diversity of stratabound deposits, Western Stara Planina Mt., Bulgaria.- Proc. VIth Intern. Symp. "Mineral Diversity. Research and Preservation", 7-10 Oct. 2011, Sofia, 223-232.

POPOV, P. (1985): Geological-tectonic and structural conditions of the formation of stratiform deposits in the Western Balkan Metallogenic Zone.- Geol. Ore Dep., 27/6, 26-34 (in Russian).

POPOV, P. (1989): Tectonic setting and structure of the Upper Cretaceous mineralisations in the Banat-Srednogorie and the West Balkan metallogenic zones (Bulgaria).- D.Sc. Thesis, Sofia (in Bulgarian).

POPOV, P., CHERNEV, E. \& ANTONOV, M. (1989): On the structure of Plakalnitsa Ore Field.- Annual Higher Inst. Min. Geol., Sofia, 25/2, 43-60 (in Bulgarian, with English summary).

RAJABI, A., RASTAD, E. \& CANET, C. (2013): Metallogeny of Permian-Triassic carbonate-hosted $\mathrm{Zn}-\mathrm{Pb}$ and $\mathrm{F}$ deposits of Iran. A review for future mineral exploration.- Australian J. Earth Sci., 60/2, 197-216.

RATIEV, L. (1977): On the pipe-like depositions of lead in the Kremikovtsi iron deposit.- In: Problems of Ore Formation, BAS Publ. House, Sofia, 541-546 (in Bulgarian).

VAPTSAROVA, A., CHEMBERSKI, H. \& NIKOLOVA, L. (1979): Le Trias dans la Bulgarie du Nord. IV. Les sediments carbonates de la Formation de Dojrenci dans la partie central de la Bulgarie du Nord.- Geologica Balc., $13 / 2,75-88$.

YOVCHEV, Y. (1961): Mineral resources of Bulgaria. Base metals. Sofia, Tehnika, $132 \mathrm{p}$.

ZAGORCHEV, I. \& BUDUROV, K. (2009): Triassic Geology.- In: ZAGORCHEV, I., DABOVSKI, C. \& NIKOLOV, T. (eds.): Geology of Bulgaria, Vol. II., Part 5. Mesozoic Geology, Sofia. Prof. Marin Drinov Publ. House, 40-102 (in Bulgarian).

ZAGORCHEV, I. \& DABOVSKI, C. (2009): Mesozoic Evolution.- In: ZAGORCHEV, I., DABOVSKI, C. \& NIKOLOV, T. (eds.): Geology of Bulgaria, Vol. II., Part 5. Mesozoic Geology, Sofia, Prof. Marin Drinov Publ. House, 21-29 (in Bulgarian). 